\title{
Lifetime Risk
}

National Cancer Institute

\section{Source}

National Cancer Institute. Lifetime Risk. NCI Thesaurus. Code C19662.

An estimate of cumulative risk calculated over a lifetime. 